\title{
Germline MUTYH gene mutations are not frequently found in unselected patients with papillary breast carcinoma
}

Ewout P Boesaard ${ }^{1 \dagger}$, Ingrid P Vogelaar ${ }^{1 \dagger}$, Peter Bult ${ }^{2}$, Carla AP Wauters ${ }^{3}$, J Han JM van Krieken², Marjolijn JL Ligtenberg ${ }^{1,2}$, Rachel S van der Post ${ }^{2}$ and Nicoline Hoogerbrugge ${ }^{1 *}$

\begin{abstract}
MUTYH-associated polyposis (MAP) is an autosomal recessive disease, which predisposes to polyposis and colorectal cancer. There is a trend towards an increased risk of breast cancer in MAP patients, with a remarkable proportion of papillary breast cancers. To determine whether MUTYH mutations are associated with this specific and rare type of breast cancer, 53 unselected patients with papillary breast cancer were analyzed for founder mutations in the MUTYH gene. No germline mutations were identified, indicating that biallelic MUTYH mutations are not a frequent underlying cause for the development of papillary carcinomas of the breast.
\end{abstract}

Keywords: MUTYH, Papillary carcinomas of the breast, MUTYH-associated polyposis

\section{Introduction}

$M U T Y H$-associated polyposis (MAP) is an autosomal recessive disease, which was first identified by El-Tassan et al. in 2002 [1]. Several studies confirmed the association between germline MUTYH mutations and colorectal adenomas and colorectal carcinomas [2-4]. The MUTYH gene is involved in base excision repair (BER) preventing $\mathrm{G}: \mathrm{C} \rightarrow \mathrm{T}: \mathrm{A}$ conversions. These conversions are caused by oxidative damage forming 8-oxo-7,8-dihydro-2-deoxyguanosine (8-oxoG) resulting in a mis-incorporation of adenine that, if not repaired by MUTYH DNA glycosylase, could lead to a G:C $\rightarrow$ T:A conversion [5-7]. In the Dutch population the mutations p.Y179C, p.G396D and p.P405L account for approximately $90 \%$ of all $M U T Y H$ germline mutations $[8,9]$.

Several studies on extracolonic cancers in MAP patients have been performed. In one study in MAP patients in which the histological subtype of the breast tumors were included, two out of eleven breast cancers were described as intracystic papillary type [10]. Also, the occurrence of MUTYH mutations in patients with breast cancer has

* Correspondence: nicoline.hoogerbrugge@radboudumc.n

${ }^{\dagger}$ Equal contributors

1 Department of Human Genetics, Radboud university medical center, P.O.

Box 9101, 6500 HB, Nijmegen, The Netherlands

Full list of author information is available at the end of the article been examined. Some of these studies found a significant increase in MUTYH mutations in breast cancer patients, while others could not find this potential association. [11-15]. Two of these studies specified the breast cancer histological subtypes of the patients. Out et al. found that minor allele genotypes of several MUTYH variants showed a trend towards association with lobular BC histology [14], while Rennert et al. found no differences for ductal or other $\mathrm{BC}$ histology type among 30 patients heterozygous for p.Gly396Asp or p.Tyr179Cys and 359 patients homozygous wild-type for these mutations [15].

Intracystic papillary breast cancer accounts for less than $1 \%$ of the total amount of breast cancer $[16,17]$, however, this type has been observed in an unexpectedly high proportion of MAP patients. We therefore wondered whether papillary carcinomas of the breast could be used as a hallmark to recognize patients with MAP. To explore whether biallelic MUTYH mutations are a frequent cause underlying the development of papillary carcinomas of the breast, we analyzed the prevalence of germline $M U T Y H$ mutations in an unselected patient group with papillary breast cancer. 
Table 1 Primers used for amplification

\begin{tabular}{|c|c|c|c|}
\hline Variant & Forward primer (5' - 3') & Reverse primer (5' - 3') & Product \\
\hline p.Y179C & CCCCCTAGCTCCTCTACCAC & CGGGTGATCTCTTTGACCTC & $202 \mathrm{bp}$ \\
\hline p.G396D and p.P405L & AGCCCAACGCTGTAGTTCCT & GAGGGCAGTGGCATGAGTAA & $182 \mathrm{bp}$ \\
\hline
\end{tabular}

$\mathrm{Bp}=$ Base pair

\section{Methods}

\section{Patient samples}

The study group consisted of 74 patients with papillary carcinomas of the breast, including papillary ductal carcinoma in situ (DCIS), intraductal/intracystic papillary carcinomas and invasive papillary carcinomas, which were diagnosed between January 1990 and December 2012 in the Radboud university medical center, and between January 2002 and December 2012 in the Canisius Wilhelmina Hospital, Nijmegen. Cases were retrieved from the surgical pathology files. Information concerning other malignancies or polyposis coli was obtained from pathology records using the PALGA (nationwide histopathology and cytopathology data archive of the Netherlands) database. All records were anonymously listed in a database. Cases were treated according to the FEDERA (Dutch Federation of Biomedical Societies) code, with anonymous use of redundant tissue for research purposes.

\section{DNA analysis}

DNA was isolated from formalin-fixed paraffin-embedded (FFPE) tissue. Preferably normal ("benign") tissue was selected. If no benign tissue was available, which was the case for two patients, tissue containing tumor material was used. FFPE tissue was reviewed to exclude presence of tumor cells before and after DNA isolation with H\&E-stained slides. DNA concentration of the samples was measured using the Nanodrop ND-1000 (Thermo Fisher Scientific, USA) and Qubit 1.0 (Life Technologies Corporation, UK). The quality of samples

Table 2 Patient characteristics

\begin{tabular}{|c|c|c|}
\hline Patients, $\mathrm{n}$ & Sequenced $(N=53)$ & All patients $(\mathrm{N}=72)$ \\
\hline Sex (Male/Female) & 52 female, 1 male & 71 female, 1 male \\
\hline $\begin{array}{l}\text { Age at diagnosis } \\
\text { (range) }\end{array}$ & $\begin{array}{l}67.5 \text { years (range } \\
22-89 \text { years) }\end{array}$ & $\begin{array}{l}67.4 \text { years (range } \\
22-96 \text { years) }\end{array}$ \\
\hline \multicolumn{3}{|l|}{ Histological type } \\
\hline - Papillary DCIS & $3(5.7 \%)$ & $6(8.3 \%)$ \\
\hline $\begin{array}{l}\text { - Intraductal/ } \\
\text { intracystic PC }\end{array}$ & $39(73.6 \%)$ & 49 (68.1\%) \\
\hline $\begin{array}{l}\text { - PC with invasive } \\
\text { component }\end{array}$ & 11 (20.8\%) & $17(23.6 \%)$ \\
\hline $\begin{array}{l}\text { Patients with colon } \\
\text { adenomas }\end{array}$ & $9(17.0 \%)$ & $9(12.5 \%)$ \\
\hline $\begin{array}{l}\text { Patients with colon } \\
\text { carcinoma }\end{array}$ & $3(5.7 \%)$ & $4(5.6 \%)$ \\
\hline
\end{tabular}

$\mathrm{PC}=$ Papillary carcinoma; DCIS = Ductal carcinoma in situ. was evaluated by performing a DNA size ladder polymerase chain reaction (PCR). Patients for whom the isolated DNA was of insufficient quality were excluded from the study. MUTYH primers were developed using the UCSC Browser (Table 1) and the DNA was amplified using PCR. The PCR product was enzymatically purified, after which sequencing was performed using Big-Dye terminator sequencing (BigDye Terminators $\mathrm{v}$ 1.1 (Applied Biosystems, USA)). The sequence data was analyzed using Vector NTI advance V11.0 (Invitrogen corporations, USA) and Chromas Lite (Technelysium, Australia). The following three founder mutations were evaluated; c.536A $>$ G (p.Y179C), c.1187G $>$ A (p.G396D) and c.1214C $>$ T (p.P405L). MUTYH mutations were annotated according to the most recent version of the reference sequence, NM_001128425.1.

\section{Results}

Tissue was available from 72 of in total 74 patients with papillary breast cancer; benign tissue was available from 70 patients and for two patients we used malignant tissue. Patient characteristics are depicted in Table 2. Six patients $(8.3 \%)$ had a DCIS of the papillary type, 49 patients $(68.1 \%)$ had an intraductal or intracystic papillary carcinoma with no signs of invasion in the surrounding tissue and in 17 patients (23.6\%) an invasive component was found which originated from the intraductal or intracystic papillary carcinoma or papillary type DCIS. Within our total cohort of breast cancer patients, 9 patients were also diagnosed with at least 1 adenoma of the colon and 4 patients with a metachronous or synchronous colon carcinoma were present.

From 53 patients (73.6\%), including 9 patients with a colorectal adenoma and 3 patients with a colon carcinoma, the quality of the isolated DNA was sufficient for further use in analysis of the three most common founder mutations in the Dutch population. The average age was 67 years (SD 13 years) with a range of 22 to 96 years, which is comparable with a population wide study on patients with a papillary carcinoma of the breast [18]. No MUTYH mutations were found (Table 3).

Table 3 Mutation analysis

\begin{tabular}{llll}
\hline Patients, $\mathbf{n}$ & p.Y179C & p.G396D & p.P405L \\
\hline$N=53$ & $0 / 53$ & $0 / 53$ & $0 / 53$ \\
\hline
\end{tabular}




\section{Discussion}

Our data do not confirm that biallelic germline MUTYH mutations are a frequent underlying cause of papillary carcinomas of the breast. Such relation was previously suggested by the results of Vogt et al. that showed an overrepresentation of intraductal papillary carcinomas of the breast in a MAP cohort [10]. Papillary carcinomas of the breast are a group of tumors with a favorable prognosis [19]. The terminology of papillary carcinomas has been widely disputed. The intraductal and intracystic papillary carcinomas were first considered as a form of carcinoma in situ, but it was shown that they often completely lack a myoepithelial layer and can be invasive [20]. Some authors prefer to use the term encapsulated papillary carcinoma, which refers to intracystic and solid papillary tumors, which are circumscribed and mostly have a fibrous capsule [21]. For this article, we have made a differentiation between papillary DCIS, intraductal or intracystic papillary carcinomas and papillary carcinomas with an invasive component. As the definition of the various histological variants of this malignant tumor differs in the literature, we decided to include in our study all the previously described papillary tumors. In our study, papillomas of the breast were excluded because a relation between this benign tumor and malignant papillary carcinomas has not been described.

In our study we could not identify the association between MUTYH mutations and papillary carcinomas of the breast in an unselected group of patients with papillary carcinomas. The current approach has been used in other studies in cancer predisposition syndromes. For example, patients with Familial Adenomatous Polyposis, caused by mutations in the $A P C$ gene, have a higher risk of developing desmoid tumors, but when a unselected cohort of this rare type of tumor is tested for $A P C$ mutations, only a small mutation detection rate has been found $[22,23]$. The same accounts for patients with endometrial cancer that are screened for Lynch syndrome-predisposing genes [24,25].

Based on the data presented in this study, an enrichment of biallelic MUTYH mutations in other patient cohorts cannot be excluded. This might be true for patients with other histological subtypes of $\mathrm{BC}$, patients with very early onset of papillary carcinoma, patients with papillary carcinomas of the breast together with polyposis as well as patients with a family history of colon carcinomas. Our data, however, do indicate that papillary carcinomas of the breast cannot be used as a hallmark to recognize patients with $M U T Y H$-associated polyposis.

\section{Competing interests}

The authors declare that they have no competing interests.

\section{Authors' contributions}

$\mathrm{NH}$ designed the study. EPB, CAPW and RSVDP were involved in selection of patients. PB, JHJMVK and RSVDP provided pathology expertise. DNA isolation and sequencing analysis, including data-analysis, was performed by EPB and
IPV. EPB, IPV, MJLL, RSVDP and NH wrote the manuscript. All authors read, contributed to and approved the final manuscript.

\section{Acknowledgements}

The authors thank Manja Weijers, Department of Pathology, for excellent technical assistance.

\section{Author details}

'Department of Human Genetics, Radboud university medical center, P.O. Box 9101, 6500 HB, Nijmegen, The Netherlands. ' ${ }^{2}$ epartment of Pathology, Radboud university medical center, Nijmegen, The Netherlands. ${ }^{3}$ Department of Pathology, Canisius Wilhelmina Hospital, Nijmegen, The Netherlands.

Received: 1 May 2014 Accepted: 26 November 2014 Published: 12 December 2014

\section{References}

1. Al-Tassan N, Chmiel NH, Maynard J, Fleming N, Livingston AL, Williams GT, Hodges AK, Davies DR, David SS, Sampson JR, Cheadle JP: Inherited variants of MYH associated with somatic G:C-> T:A mutations in colorectal tumors. Nat Genet 2002, 30:227-232.

2. Jones S, Emmerson P, Maynard J, Best JM, Jordan S, Williams GT, Sampson JR, Cheadle JP: Biallelic germline mutations in MYH predispose to multiple colorectal adenoma and somatic G:C-> T:A mutations. Hum Mol Genet 2002, 11:2961-2967.

3. Sampson JR, Dolwani $\mathrm{S}$, Jones $\mathrm{S}$, Eccles $\mathrm{D}$, Ellis $\mathrm{A}$, Evans DG, Frayling I, Jordan S, Maher ER, Mak T, Maynard J, Pigatto F, Shaw J, Cheadle JP: Autosomal recessive colorectal adenomatous polyposis due to inherited mutations of MYH. Lancet 2003, 362:39-41.

4. Sieber OM, Lipton L, Crabtree M, Heinimann K, Fidalgo P, Phillips RK, Bisgaard ML, Orntoft TF, Aaltonen LA, Hodgson SV, Thomas HJ, Tomlinson IP: Multiple colorectal adenomas, classic adenomatous polyposis, and germ-line mutations in MYH. N Engl J Med 2003, 348:791-799.

5. Shibutani S, Takeshita M, Grollman AP: Insertion of specific bases during DNA synthesis past the oxidation-damaged base 8-oxodG. Nature 1991, 349:431-434.

6. Slupska MM, Luther WM, Chiang JH, Yang H, Miller JH: Functional expression of hMYH, a human homolog of the Escherichia coli MutY protein. J Bacteriol 1999, 181:6210-6213.

7. Takao M, Zhang QM, Yonei S, Yasui A: Differential subcellular localization of human MutY homolog (hMYH) and the functional activity of adenine:8-oxoguanine DNA glycosylase. Nucleic Acids Res 1999, 27:3638-3644.

8. Nielsen $M$, Franken PF, Reinards TH, Weiss MM, Wagner A, van der Klift $H_{\text {, }}$ Kloosterman S, Houwing-Duistermaat JJ, Aalfs CM, Ausems MG, BrockerVriends AH, Gomez Garcia EB, Hoogerbrugge N, Menko FH, Sijmons RH, Verhoef S, Kuipers EJ, Morreau H, Breuning MH, Tops CM, Wijnen JT, Vasen HF, Fodde R, Hes FJ: Multiplicity in polyp count and extracolonic manifestations in 40 Dutch patients with MYH associated polyposis coli (MAP). J Med Genet 2005, 42:e54.

9. Van Puijenbroek M, Nielsen M, Tops CM, Halfwerk H, Vasen HF, Weiss MM, Van Wezel T, Hes FJ, Morreau H: Identification of patients with (atypical) MUTYH-associated polyposis by KRAS2 c.34G > T prescreening followed by MUTYH hotspot analysis in formalin-fixed paraffin-embedded tissue. Clin Cancer Res 2008, 14:139-142.

10. Vogt S, Jones N, Christian D, Engel C, Nielsen M, Kaufmann A, Steinke V, Vasen HF, Propping P, Sampson JR, Hes FJ, Aretz S: Expanded extracolonic tumor spectrum in MUTYH-associated polyposis. Gastroenterology 2009, 137:1976-1985. e1971-1910.

11. Beiner ME, Zhang WW, Zhang S, Gallinger S, Sun P, Narod SA: Mutations of the MYH gene do not substantially contribute to the risk of breast cancer. Breast Cancer Res Treat 2009, 114:575-578.

12. Zhang Y, Newcomb PA, Egan KM, Titus-Ernstoff L, Chanock S, Welch R, Brinton LA, Lissowska J, Bardin-Mikolajczak A, Peplonska B, Szeszenia-Dabrowska N, Zatonski W, Garcia-Closas M: Genetic polymorphisms in base-excision repair pathway genes and risk of breast cancer. Cancer Epidemiol Biomarkers Prev 2006, 15:353-358.

13. Wasielewski M, Out AA, Vermeulen J, Nielsen $M$, van den Ouweland A, Tops CM, Wijnen JT, Vasen HF, Weiss MM, Klijn JG, Devilee P, Hes FJ, Schutte M: Increased MUTYH mutation frequency among Dutch families with breast cancer and colorectal cancer. Breast Cancer Res Treat 2010, 124:635-641. 
14. Out AA, Wasielewski M, Huijts PE, Van Minderhout IJ, Houwing-Duistermaat JJ, Tops CM, Nielsen M, Seynaeve C, Wijnen JT, Breuning MH, Van Asperen CJ, Schutte M, Hes FJ, Devilee P: MUTYH gene variants and breast cancer in a Dutch case-control study. Breast Cancer Res Treat 2012, 134:219-227.

15. Rennert G, Lejbkowicz F, Cohen I, Pinchev M, Rennert HS, Barnett-Griness O: MutYH mutation carriers have increased breast cancer risk. Cancer 2012, 118:1989-1993.

16. Li Cl, Moe RE, Daling JR: Risk of mortality by histologic type of breast cancer among women aged 50 to 79 years. Arch Intern Med 2003, 163:2149-2153.

17. Louwman MW, Vriezen M, Van Beek MW, Nolthenius-Puylaert MC, van der Sangen MJ, Roumen RM, Kiemeney LA, Coebergh JW: Uncommon breast tumors in perspective: incidence, treatment and survival in the Netherlands. Int I Cancer 2007, 121:127-135.

18. Grabowski J, Salzstein SL, Sadler GR, Blair S: Intracystic papillary carcinoma: a review of 917 cases. Cancer 2008, 113:916-920.

19. Lefkowitz M, Lefkowitz W, Wargotz ES: Intraductal (intracystic) papillary carcinoma of the breast and its variants: a clinicopathological study of 77 cases. Hum Pathol 1994, 25:802-809.

20. Wynveen CA, Nehhozina T, Akram M, Hassan M, Norton L, Van Zee KJ, Brogi E: Intracystic papillary carcinoma of the breast: an in situ or invasive tumor? Results of immunohistochemical analysis and clinical follow-up. Am J Surg Pathol 2011, 35:1-14.

21. Collins LC, Carlo VP, Hwang H, Barry TS, Gown AM, Schnitt SJ: Intracystic papillary carcinomas of the breast: a reevaluation using a panel of myoepithelial cell markers. Am J Surg Pathol 2006, 30:1002-1007.

22. Kattentidt Mouravieva AA, Geurts-Giele IR, De Krijger RR, Van Noesel MM, van de Ven CP, van den Ouweland AM, Kromosoeto JN, Dinjens WN, Dubbink HJ, Smits R, Wagner A: Identification of Familial Adenomatous Polyposis carriers among children with desmoid tumours. Eur J Cancer 2012, 48:1867-1874.

23. Wang WL, Nero C, Pappo A, Lev D, Lazar AJ, Lopez-Terrada D: CTNNB1 genotyping and APC screening in pediatric desmoid tumors: a proposed algorithm. Pediatr Dev Pathol 2012, 15:361-367.

24. Ferguson SE, Aronson M, Pollett A, Eiriksson LR, Oza AM, Gallinger S, Lerner-Ellis J, Alvandi Z, Bernardini MQ, MacKay HJ, Mojtahedi G, Tone AA, Massey C, Clarke BA: Performance characteristics of screening strategies for Lynch syndrome in unselected women with newly diagnosed endometrial cancer who have undergone universal germline mutation testing. Cancer 2014, 120:3932-3939.

25. Hampel H, Frankel W, Panescu J, Lockman J, Sotamaa K, Fix D, Comeras I, La Jeunesse J, Nakagawa H, Westman JA, Prior TW, Clendenning M, Penzone P, Lombardi J, Dunn P, Cohn DE, Copeland L, Eaton L, Fowler J, Lewandowski G, Vaccarello L, Bell J, Reid G, de la Chapelle A: Screening for Lynch syndrome (hereditary nonpolyposis colorectal cancer) among endometrial cancer patients. Cancer Res 2006, 66:7810-7817.

doi:10.1186/1897-4287-12-21

Cite this article as: Boesaard et al:: Germline MUTYH gene mutations are not frequently found in unselected patients with papillary breast carcinoma. Hereditary Cancer in Clinical Practice 2014 12:21.

\section{Submit your next manuscript to BioMed Central and take full advantage of:}

- Convenient online submission

- Thorough peer review

- No space constraints or color figure charges

- Immediate publication on acceptance

- Inclusion in PubMed, CAS, Scopus and Google Scholar

- Research which is freely available for redistribution 